\title{
Confirmation of mosaic trisomy 22 in an infant with failure to thrive
}

\author{
*Kavinda Chandimal Dayasiri1 ${ }^{1}$, Deepthi De Silva ${ }^{2}$, Kumudu Weerasekara $^{1}$
}

Sri Lanka Journal of Child Health, 2018; 47(2): 174-176

DOI: http://dx.doi.org/10.4038/sljch.v47i2.8488

(Key words: Mosaic trisomy 22, failure to thrive)

\section{Introduction}

Chromosome mosaicism is defined as the presence of two or more karyotypically different cell lines in an individual ${ }^{1}$. These two cell lines occur as a post zygotic event but other mechanisms are also described $^{2}$. Mosaicism is associated with the live birth of infants with chromosome anomalies that are not detected in non-mosaic forms and the mosaicism may be present at low levels in tissues making cytogenetic confirmation difficult. In some cases, the mosaicism is confined to a single tissue adding to the complexity of diagnosis ${ }^{3}$. We report a child with clinical features of mosaicism in whom the diagnosis of mosaic trisomy 22 was confirmed.

\section{Case report}

A $4 \frac{1}{2}$ year old girl who was the second child of healthy, unrelated parents presented for further evaluation of poor growth. She was born at term with symmetrical intrauterine growth retardation: birth weight $1.8 \mathrm{~kg}(<-3 \mathrm{SD})$, occipito-frontal circumference (OFC) $31 \mathrm{~cm}\left(<5^{\text {th }}\right.$ centile) and length $46 \mathrm{~cm}(<-3 \mathrm{SD})$. She had a cleft of her soft palate which was repaired at nine months of age and ventricular septal defect closed at 10 months of age. She also had severe feeding difficulty associated with severe gastro-esophageal reflux disease and complicated with recurrent aspiration pneumonias necessitating gastrostomy feeding.

On examination, she had severe growth retardation with a weight of $8.8 \mathrm{~kg}(<-3 \mathrm{SD})$, height of $85 \mathrm{~cm}(<-$ $3 \mathrm{SD})$ and an OFC of $41 \mathrm{~cm}(<-3 \mathrm{SD})$. She had linear hypopigmentation along the lines of Blaschko in both upper limbs, left sided facial, limb and trunk hypoplasia [with leg length discrepancy of $3 \mathrm{~cm}$ ] and a mild scoliosis. The hypoplasia of the left lower limb is shown in Figures 1 and 2.

${ }^{1}$ Lady Ridgeway for Hospital for Children, Colombo, Sri Lanka, ${ }^{2}$ Faculty of Medicine, University of Kelaniya, Ragama, Sri Lanka

*Correspondence: mbkcdayasiri@gmail.com

(Received on 03 November 2016: Accepted after revision on 23 December 2016)

The authors declare that there are no conflicts of interest

Personal funding was used for the project.

Open Access Article published under the Creative

Commons Attribution CC-BY

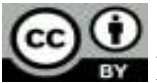

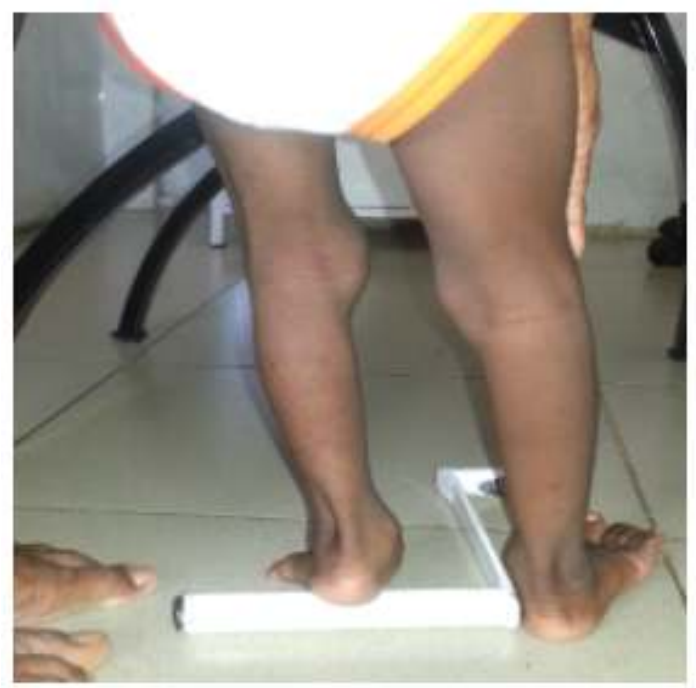

Figure 1: Hypoplasia of left lower limb

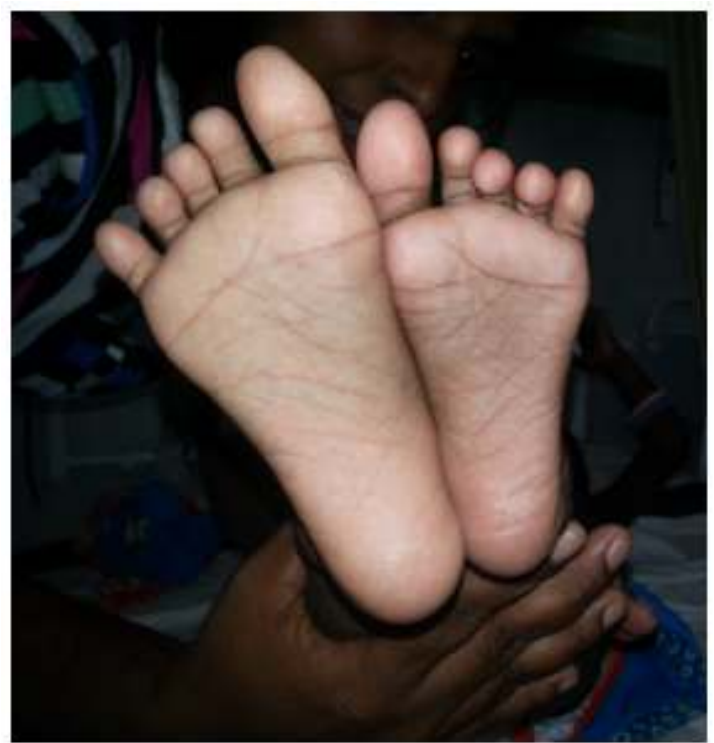

Figure 2: Hypoplasia of left lower limb

She also had hypertelorism, micrognathia and bilateral pre-auricular pits. Her development was globally delayed (gross motor 1 year, fine motor 1 $1 / 2$ years, speech $1 \frac{1}{2}$ years, social 2 years). She had central hypertonia with joint hypermobility and bilateral genu recurvatum. Her neck and posterior hairline were normal.

Initial echocardiography revealed a restrictive perimembranous ventricular septal defect and 
hypoplastic transverse aortic arch. Hearing assessment using audiometry, ultrasound scan of renal tract, magnetic resonance imaging of brain and electroencephalogram were normal and eye examination showed no colobomata. Chromosome testing revealed mosaic trisomy 22 syndrome (47, $\mathrm{XX},+22(03) / 46, \mathrm{XX})$

\section{Discussion}

Trisomy 22 is the second most common autosomal trisomy found in fetal life and accounts for 3-5\% of all spontaneous abortions ${ }^{4}$. However, mosaic trisomy 22 in live born infants has been reported in only around 20 cases as per recently published reviews ${ }^{5}$. The clinical features of Trisomy 22 are variable and are presumed to be dependent on the proportion of the trisomic cell line in each tissue. They include constant features such as mental retardation, growth retardation, microcephaly, cryptorchidism (males), very frequent $(>80 \%)$ features such as muscle underdevelopment/ hypotonia, micrognathia, cleft palate, large low-set malformed ears, pre-auricular tags and/or sinuses, long slender fingers and/or finger-like thumbs, congenital heart disease, congenital hip dislocation and frequent $(>60 \%)$ features such as craniofacial asymmetry, long and beaked nose, long philtrum and strabismus ${ }^{6,7}$. Described clinical manifestations include microcephaly, hypertelorism, epicanthic folds, hypoplastic or low set ears, mid-face hypoplasia, hypoplastic distal phalanges, abnormalities of male genitalia, pre and postnatal growth retardation, cleft palate, cardiac and/or renal anomalies and anal atresia/stenosis ${ }^{8}$. This case did not have the major anal, ear or eye malformations [especially the 'cat eye' sign caused by iris coloboma] that are classically associated with this syndrome. The presence of some but not all the described malformations is consistent with the variability of the condition, which in turn reflects the proportion of the trisomic cells in each tissue or organ.

The presence of linear pigmentary anomalies [either hyper or hypopigmentation] along the lines of Blaschko associated with the presence of asymmetry of the body is typical of a mosaic genetic disorder. Such mosaicism could be due to a chromosome disorder ${ }^{9}$ or a single gene disorder ${ }^{10}$. Some of the mosaic disorders are clinically distinct and therefore recognizable ${ }^{11,12}$ while many are less easily diagnosed due to the nonspecific nature of the findings.

Establishing a genetic diagnosis enables better management including investigations for the associated problems as well as more accurate counselling of the parents regarding the prognosis and recurrence risks. Genetic testing in a child with developmental delay and features suggestive of a mosaic disorder would begin with karyotyping but it is necessary to alert the laboratory for the need to count a larger number of cells on blood karyotype to identify a mosaicism of low frequency ${ }^{13}$. When available, comparative genomic hybridization is the preferred method of diagnosis ${ }^{14}$ as its positive yield is higher than with conventional karyotyping. In addition, the use of a buccal cells ${ }^{15}$ or fibroblasts ${ }^{16}$ for testing is more likely to identify the abnormality.

\section{Acknowledgements}

We thank the cytogenetics laboratory, Asiri Hospital for performing karyotyping on this infant.

\section{References}

1. Robberecht C, Fryns J-P, Vermeesch JR. Piecing together the problems in diagnosing low-level chromosomal mosaicism. Genome Medicine 2010; 2:47. https://doi.org/10.1186/gm168 PMid: 20670383 PMCid: PMC2923739

2. Taylor H, Gitlin SA, Patrick JL, Crain JL, Wilson JM, Griffin DK. The origin, mechanisms, incidence and clinical consequences of chromosomal mosaicism in humans. Human Reproduction Update 2014; 20(4): 571-81. https://doi.org/10.1093/humupd/dmu016 PMid: 24667481

3. Gajecka M. Unrevealed mosaicism in the next-generation sequencing era. Molecular Genetics and Genomics. 2016; 291: 51330.

https://doi.org/10.1007/s00438-015-11307

PMid: 26481646 PMCid: PMC4819561

4. Mokate T, Leask K, Mehta S, Sharif S, Smith A, Saxena A, et al. Non-mosaic trisomy 22: a report of two cases. Prenatal Diagnosis 2006; 26: 962-5. https://doi.org/10.1002/pd.1537

PMid: 16906599

5. Abdelgadir D, Nowaczyk MJ, Li C. Trisomy 22 mosaicism and normal developmental outcome: report of two patients and review of the literature. American Journal of Medical Genetics Part A. 2013; 161A (5):1126-31. https://doi.org/10.1002/ajmg.a.35812 PMid: 23529842 
6. Mollica F, Sorge G, Pavone L. Trisomy 22 mosaicism. Journal of Medical Genetics 1977; 14(3): 224-5.

https://doi.org/10.1136/jmg.14.3.224

PMid: 881717 PMCid: PMC1013564

7. Penchaszadeh VB, Coco R. Trisomy 22. Two new cases and delineation of the phenotype. Journal of Medical Genetics 1975; 12(2): 193-9.

https://doi.org/10.1136/jmg.12.2.193

8. Bacino CA, Schreck R, Fischel-Ghodsian N, Pepkowitz S, Prezant TR, Graham JM. Clinical and molecular studies in full trisomy 22: further delineation of the phenotype and review of the literature. American Journal of Medical Genetics 1995; 56:359-65.

https://doi.org/10.1002/ajmg.1320560404

PMid: 7604844

9. Flannery DB, Byrd JR, Freeman WE, Perlman SA. Hypomelanosis of Ito: A cutaneous marker of chromosomal mosaicism. American Journal of Human Genetics 1985; 37:A93.

10. Gartler SM, Francke U. Half chromatid mutations: transmission in humans? American Journal of Human Genetics 1975; 27: 218- 23.

PMid: 1124765 PMCid: PMC1762757

11. Peltomaki, P., Knuutila, S., Ritvanen, A., Kaitila, I., de la Chapelle, A. PallisterKillian syndrome: cytogenetic and molecular studies. Clinical Genetics 1987; 31: 399-405.

https://doi.org/10.1111/j.13990004.1987.t

b02832.x

PMid: 2887316

12. Warburton, D., Anyane-Yeboa, K., Francke, U. Mosaic tetrasomy 12p: four new cases, and confirmation of the chromosomal origin of the supernumerary chromosome in one of the PallisterMosaic syndrome cases. American Journal of Medical Genetics 1987; 27: 275-83.

https://doi.org/10.1002/ajmg.1320270205

PMid: 3605213
13. Westlander G, Ekerhovd E, Granberg S, Hanson L, Hanson C, Bergh C. Testicular ultrasonography and extended chromosome analysis in men with nonmosaic Klinefelter syndrome: a prospective study of possible predictive factors for successful sperm recovery. Fertility and Sterility 2001; 75: 1102-5. https://doi.org/10.1016/S00150282(01)01 793-9

14. Scott SA, Cohen N, Brandt T, Toruner G, Desnick RJ, Edelmann L. Detection of low-level mosaicism and placental mosaicism by oligonucleotide array comparative genomic hybridization. Genetics in Medicine 2010; 12: 85-92. https://doi.org/10.1097/GIM.0b013e3181c c75d0

PMid: 20084009

15. Sdano, M.R., Vanzo, R.J., Martin, M.M. et al. Clinical Utility of Chromosomal Microarray Analysis of DNA from Buccal Cells: Detection of Mosaicism in Three Patients. Journal of Genetic Counseling 2014; 23: 922.

https://doi.org/10.1007/s10897-014-97512

PMid: 25120037

16. Ferreira AP, Mazzucatto LF, Ramos ES, Pina-Neto JM. Trisomy 13 mosaicism demonstrated only in skin fibroblasts in a patient presenting psychomotor retardation, pigmentary dysplasia and some dysmorphic features. Brazilian Journal of Genetics 1996; 19:655-7. https://doi.org/10.1590/S01008455199600 0400023 